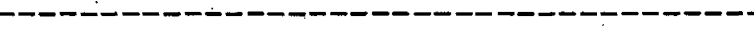

SPEAKING YOUR MIND WITHOUT ELECTIONS,

SURVEYS, OR SOCIAL MOVEMENTS

Charles Tilly

University of Michigan

August 1983

CRSO Working Paper 298

Copies available through:

Center for Research on Social

Organization

University of Michigan

330 Packard Street

Ann Arbor, Michigan 48104 


\title{
SPEAKING YOUR MIND WITHOUT ELECTIONS, SURVEYS, OR SOCIAL MOVEMENTS
}

\author{
Charles Tilly \\ University of Michigan \\ August 1983
}

\begin{abstract}
REVISED VERSION OF
ADDRESS TO THE ANNUAL MEETING OF THE AMERICAN ASSOCIATION FOR PUBLIC OPINION RESEARCH, BUCK HILL FALLS, PENNSYLVANIA
\end{abstract}


GENERAL NOTE: I wrote the original version of this paper as a commentary on eighty slides showing real events in England, France, and North America from 1550 to 1983. A version without the slides lacks color in more senses than one. Perhaps my readers can close their eyes periodically to conjure up images of processions, street fighting, demonstrations, and the sacking of wrongdoers' houses, as suggested by the text. I only hope that, having closed their eyes, they will not find it too difficult to open them again. 


\section{Looking Backward to See Forward}

When Paul Lazarsfeld gave his 1950 presidential address to the American Association for Public Opinion Research, he made his topic "The Obligations of the 1950 pollster to the 1984 Historian". In that characteristically wide-ranging talk, Lazarsfeld closed in on a simple but important point: Historians' explanations of social behavior often depend on imputations of attitudes to crucial actors, yet they usually have weaker evidence concerning attitudes than any other feature of their accounts. The pollster of 1950, said Lazarsfeld, being a specialist in the systematic documentation of attitudes, could greatly strengthen the position of future historians. "If for a given period we not only know the standard of living, but also the distribution of ratings on happiness and personal adjustment," he said, "the dynamics of social change will be much better understood" (Lazarsfeld 1982: 94): By 1984, Lazarsfeld thought, instead of the constant obliteration of the past described in George orwell's totalitarian nightmare, we might have a kind of social bookkeeping that would integrate behaviors and attitudes into a better understanding of social change. The analysis of public opinion, he suggested, might even become a predictive science, a science of sentiments (Lazarsfeld 1982: 95).

A resurrected Paul Lazarsfeld would probably be disappointed 
with the progress we have made since 1950 in our integration of behaviors and attitudes as well as in our understanding of social change. Nevertheless, past surveys have, as Lazarsfeld hoped, begun to make their way into historians' evidence. Perhaps 1984 would be a good year for a fitting memorial to Paul Lazarsfeld: Someone should review how well the work of pollsters as bookkeepers and of historians as auditors has gone over the last three or four decades. The task of this essay, however, is rather different. It is to probe the spot in historical evidence marked by interests, complaints, demands, and aspirations -- by attitudes, in a loose sense of the word -- and see how weak it is. That attitudinal spot will turn out to be somewhat tougher than it seems. Certainly the historical record contains few reliable traces of people's inner dialogues, hidden fantasies, suppressed anxieties, or unstated preferences. But through a wide variety of collective action ordinary people have left a trail of interests, complaints, demands, and aspirations that remains visible to observers who know where to look. What is more, those varieties of collective action have changed deeply in recent history. Anyone who simply took the forms of collective action with which we are familiar today and tracked them back in time would lose the trail some time in the nineteenth century, and would soon find himself in strange terrain. 
We now live in a world in which the idea of a defined aggregate set of preferences at a national level, a sort of public opinion, makes a certain amount of sense. It makes enough sense that nowadays we can consider the opinion survey a complement to, or even an alternative to, voting, petitioning, or protesting. However, if we push back into the strange terrain of western Europe and North America before the middle of the nineteenth century, we soon discover another world. In that world, most people did not vote, petition, or take positions on national affairs in anything like the contemporary meanings of those terms. Yet they did act together on their interests, broadcasting their demands, complaints, and aspirations in no uncertain terms.

Let us explore briefly how ordinary people in western Europe and North America acted together before our own time, and what materials their action left for today's historians. Then we can examine the changes that brought our own contemporary forms of collective action into being, consider their relationship to the idea of an informed public opinion, and explore why they occurred. To simplify things, my examples will come exclusively from France, Great Britain, and the United States, and mainly from just three cities: Paris, London, and Boston. Those examples should be enough to show that we have rich historical material to work with, even in the absence of elections, surveys, and text-producing 
social movements.

\section{What Changed, and why?}

Before the narrative, a schematic summary of the underlying analysis. Any population has a limited repertoire of collective action: alternative means of acting together on shared interests. In our time, most people know how to participate in an electoral campaign, join or form a special-interest association, organize a letter-writing drive, demonstrate, strike, hold a meeting, build an influence network, and so on. These varieties of action constitute a repertoire in something like the theatrical or musical sense of the word - but the repertoire in question resembles that of commediadell'arte or jazz more than that of a strictly classical ensemble. People know the general rules of performance more or less well, and vary the performance to meet the purpose at hand. Every performance involves at least two parties - an initiator and an object of the action. Third parties often get involved; even when they are not the object of collective action, for example, agents of the state spend a good deal of their time monitoring, regulating, facilitating, and repressing different sorts of collective action.

The existing repertoire constrains collective action; far from the image we sometimes hold of mindless crowds, people tend to act within known limits, to innovate at the margins of existing 
forms, and to miss many opportunities available to them in principle. That constraint results in part from the advantages of familiarity, partly from the investment of second and third parties in the established forms of collective action. Although it may seem otherwise, even government officials and industrial managers of our own time generally behave as though they preferred demonstrations and strikes to utterly unconventional forms of collective action.

Let me concentrate on the more discontinuous and public forms of collective action: striking, demonstrating, occupying, and so on rather than building influence networks or operating special-interest organizations. Although changes in continuous and private forms of collective action have also been profound, they are harder to document than are relatively discontinuous public forms. The main reasons for that difference in documentation are simple and important: First, in most of the discontinuous and public forms of action the point is to make a statement of some kind. Deliberate public statements tend to leave behind more documentation than other varieties of collective action. Second, authorities generally monitor and seek to control. discontinuous and public forms because of their implicit claims on the existing structure of power. Hence surveillance reports, instructions to spies and cops, memoranda to interior ministers 
and the like fill the archives of former authorities.

What do those archives tell us? Some time in the nineteenth century, the people of most western countries shed the collective-action repertoire they had been. using for two centuries or so, and adopted the repertoire they still use today. The exact timing, pace, and character of the transfer varied from country to country and group to group: generally early in England, later in France, later yet in Germany, and so on. In England, for example, distinct collective-action innovations appeared in the $1760 \mathrm{~s}$ and $177 \emptyset \mathrm{s}$, yet most collective action took the older forms into the $1820 \mathrm{~s}$, and the really rapid transformation came in the $1830 \mathrm{~s}$, around the time of the first great Reform Bill. By the later $184 \emptyset \mathrm{s}$, the new repertoire clearly dominated English collective action. France, on the other hand, did not complete a definitive shift to the new repertoire until the $1850 \mathrm{~s}$; there, the Revolution of 1848 provided a stimulus similar to that of the Reform mobilization in England.

What was the difference? Broadly speaking, the repertoire of the seventeenth to nineteenth centuries held to a parochial scope: It addressed local actors or the local representatives of national actors. It also relied heavily on patronage - appealing to immediately available powerholders to convey grievances or settle disputes, temporarily acting in the place of unworthy or inactive 


\section{CHARACTERISTICS OF THE REPERTOIRE OF POPULAR COLLECTIVE ACTION IN WESTERN EUROPE AND NORTH AMERICA, ROUGHLY 1650-1850}

1. people's frequent employment of the authorities' normal means of action, either as caricature or as a deliberate, if temporary, assumption of the authorities' prerogatives in the name of the local community

2. Common appearance of participants as members or representatives of constituted corporate groups and communities rather than of special interests

3. a tendency to appeal to power patrons for redress of wrongs and, especially, for representation vis a vis outside authorities

4. extensive use of authorized public celebrations and assemblies for the presentation of grievances and demands

5. repeated adoption of $r i c h$, irreverent symbolism in the form of effigies, dumb show, and ritual objects to state grievances and demands

6. Convergence on the residences of wrongdoers and the sites of wrongdoing, as opposed to seats and symbols of public power

EXAMPLES :

seizures of grain = "food riots"

collective invasions of forbidden fields, forests, and streams

destruction of toll gates and other barriers

attacks on machines

Rough Music, charivari, Katzenmusik/serenade

expulsions of tax officials, foreign workers, and other outsiders

tendentious holiday parades

intervillage battles

pulling down and sacking of private houses

forced illumination

acting out of popular judicial proceedings

turnout

GENERAL CHARACTERISTICS: PAROChIAL AND PATRONIZED 
powerholders only to abandon power once the action was done. For all their labeling as "riots" and "disorders", seizures of grain, invasions of fields, machine-breaking and similar actions had a common logic and an internal order.

The repertoire that crystalized in the nineteenth century and prevails today is, in general, more national in scope: Although available for local issues and enemies, it lends itself easily to coordination among many localities. As compared with the older repertoire, its actions are relatively autonomous: instead of staying in the shadow of existing powerholders and adapting routines sanctioned by those powerholders, users of the new repertoire tend to initiate their own statements of grievances and demands. Strikes, demonstrations, electoral rallies and similar actions build, in general, on much more deliberatelyconstructed organization than used to be the case.

The social movement, as we know it, came into being with the new repertoire. My fellow sociologists have, alas, caused a great deal of confusion by combining in that category a distinctive nineteenth- and twentieth-century form of action, which they know well, with a miscellany of other religious and political actions of which they have little knowledge. The social movement consists of a series of challenges to established authorities, especially national authorities, in the name of an unrepresented 
constituency. Its concrete actions combine various elements of the newer repertoire: public meetings, demonstrations, marches, strikes, and so on, coupled with an attempt by leaders to link the actions organizationally and symbolically, as well as to bargain with established authorities on behalf of their claimed constituency. Although it does not have the official standing of an electoral campaign or a petition drive, the deliberatelyorganized social movement occupies a recognized place in our contemporary array of means for acting collectively.

Those who claim to speak for the same social movements often divide and compete. They vary enormously in their actual relationship to the constituencies they claim. Although one might make a case for the protestant Reformation or the English Revolution as full-fledged social movements in these terms, this complex of action was virtually unknown in western countries until the nineteenth century. Before then, although rebellions great and small occurred repeatedly, practically no one tried to combine seizures of grain, field invasions, turnouts, and the like into visibly sustained challenges to established authorities. Then the social movement became commonplace. On balance, its action was national in scope and autonomous with respect to powerholders.

The dichotomies parochial/national and patronage/autonomy simplify radically in two different ways. First, each cuts a 


\section{CHARACTERISTICS OF THE REPERTOIRE OF POPULAR COLLECTIVE ACTION IN WESTERN EUROPE AND NORTH AMERICA, ROUGHLY 1850-1980}

1. the employment of relatively autonomous means of action, of a kind rarely or never employed by authorities

2. frequent appearance of special interests and named associations or pseudo-associations (e.g Coalition for Justice, People United Against

3. direct challenges to rivals or authorities, especially national authorities and their representatives, rather than appeals to patrons

4. deliberate organization of assemblies for the articulation of claims

5. display of programs, slogans, signs of common membership

6. preference for action in visible public places

\section{EXAMPLES :}

strikes

demonstrations

electoral rallies

public meetings

petition marches

planned insurrections

invasions of official assemblies

social movements

electoral campaigns 
genuine continuum into just a pair of categories. In fact, real strikes, demonstrations, and the like are more or less national and autonomous, not clearly one or the other. second, the transition to more national and autonomous forms of action did not occur instantly and simultaneously. It was the net effect of many moves and counter-moves, occurring at different times for different places and types of collective action.

Turnouts, for example, were the routines by which workers in a given craft who had a grievance against the employers of their locality went from shop to shop within the locality, calling out the workers to join them in a march through the town, ended the circuit with a meeting at the edge of town, voted to make a certain set of demands, sent a delegation to the employers, declared a work stoppage, and enforced it as best they could throughout the town until they reached an agreement with the employers. The turnout was relatively local in scope, and put pressure on nearby patrons - both the employers and the local. authorities.

The firm-by-firm strike, as we know it, covers a whole town, a whole industry, or even a whole country in exceptional circumstances, but the main action generally occurs within and just outside a single workplace. Likewise, strikes allow workers to state their grievances and hopes independently of their 
conversations with their immediate employers. On the average, although only on the average, routines in the newer repertoire such as strikes, demonstrations, and public meetings involve less dependence on existing powerholders and greater scope than routines such as turnouts, field invasions, and seizures of grain. That is the point of calling the "new" repertoire relatively autonomous and national.

Why the prevailing repertoire of popular collective action underwent the change from relatively parochial and patronized to relatively national and autonomous is simple to state in principle and complex to show in practice. In principle, the shift occurred because the interests and organization of ordinary people shifted away from local affairs and powerful patrons to national affairs and major concentrations of power and capital. As capitalism advanced and national states became more powerful and centralized, local affairs and nearby patrons mattered less to the fates of ordinary people. Increasingly, holders of large capital and national power made the decisions that affected them. As a result, seizures of grain, collective invasions of fields and the like became ineffective, irrelevant, obsolete. In response to the shifts of power and capital, ordinary people invented and adopted new forms of action, creating the electoral campaign, the public meeting, the social movement, and the other elements of the newer 
"OLD" AND "NEW" REPERTOIRES IN WESTERN EUROPE AND NORTH AMERICA SCOPE OF ACTION

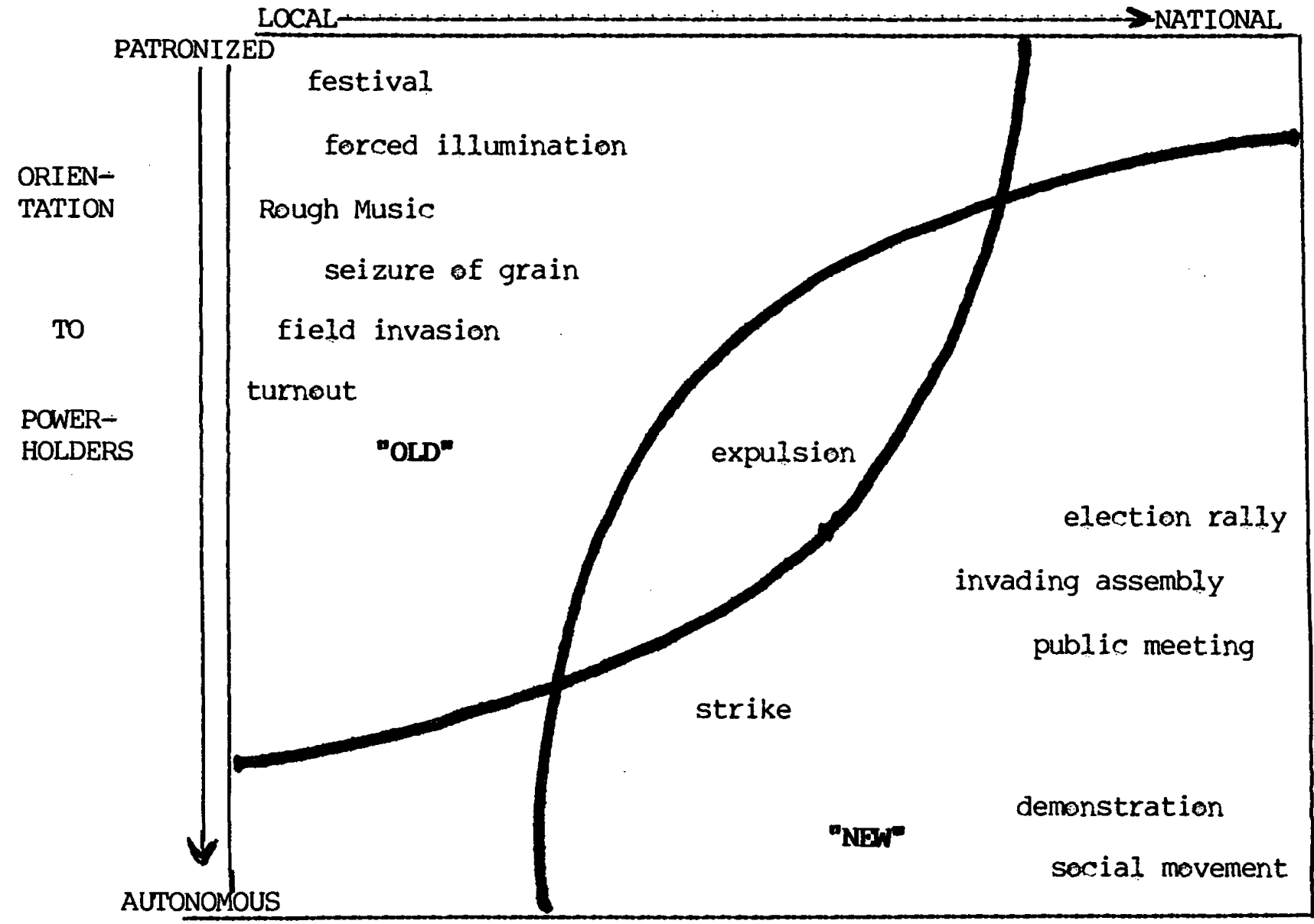


repertoire.

Although the shift in repertoires followed the logic of change in power and capital, each form and each actor had a particular history. The demonstration we know, for example, took shape in Great Britain as a series of modifications in the sending of delegates, in the holiday parade, and in other older forms. It issued, furthermore, from forty years of confrontation between radical activists and authorities. The firm-by-firm strike took on its recognizable characteristics in concrete labor-management struggles as capital concentrated in locality after locality. Because the particular histories are quite different, the common processes creating the demonstration and the strike only appear in perspective, at a distance. Nevertheless, in case after case it is clear that the common processes involved concentration -concentration of capital, concentration of political power.

surprisingly little change has occurred in the western collective-action repertoire - at least in its discontinuous and public forms - since its emergence in the nineteenth century. The main forms of action that were rare or non-existent in the nineteenth century but have become familiar in our own time have to do with occupying a space and/or the people in it. Sit-down strikes, sit-ins, collective squatting and hijacking or hostage-taking have a good deal in common. The recent emergence 
of these forms, except for hijacking and hostage-taking, has generally occurred in the company of strengthened claims by the occupiers that they have a right to control the locale -- a greater right than the usual controllers.

Although in some regards it harks back to the field invasion or the popular takeover of a festival, that assertion of prior rights to the space marks a new theme in twentieth-century collective action. Aside from that important theme and its associated actions, the only other candidate for addition to the repertoire is the creation of a thoroughly-professionalized social-movement organization: a March of Dimes or a Common Cause well-equipped with publicity, mailing lists, and lobbyists, but only thinly connected to its presumed constituency. Since manipulators and organizers of campaigns have been with us since the birth of the social movement as a standard form of collective action, this professionalization may represent no more than a refinement of practices long in existence.

01d-Regime Ritual and Revenge

old-regime France and England had nothing like Common Cause, but they did have a great many ceremonial occasions. One typical occasion for pomp was the official visit of a king, bishop, or great lord. Although authorities took great care to separate official cortege from onlookers, the spectators were an essential 
part of the event. And, when aggrieved or enthusiastic, they had the opportunity to stand silent, to shout curses, to present pleas for mercy or even to attack the dignitary's entourage.

People used that opportunity often, taking advantage of the fact that they had a right, even an obligation, to assemble on such occasions. Magistrates and troops could not therefore disperse them as unlawful assemblies. Civic processions, such as those that incessantly crossed the old City of London, became moments for complaining about municipal administration and high city taxes. Great celebrations, such as the festivities for the birth of a French royal heir, customarily included processions, tableaux, fireworks, and illuminations. Those features not only offered so many occasions to express shared satisfaction or dissatisfaction, but also provided models for other occasions -as when supporters of a popular cause ran through the streets of Paris or London forcing householders to light up their windows as a sign of solidarity.

Public punishments, such as hangings and placing people in the pillory, gave the spectators multiple opportunities. They could display opposition or support for the punishing authorities. They could cheer or criticize the hangman's performance: a bungled execution sometimes ended with the hangman's murder. And most important, they could show approval or disapproval of the victim; 
spectators ran the range from stoning the prisoner on their own to taking a collection for the person in the stocks to outright rescue of someone from the gallows.

Where authorities did not intervene directly, ordinary people had their own routines for dealing with moral offenders and moral transitions. Weddings, especially of couples seen as mismatched, and transgressions of sexual or family morality, such as adultery and wife-beating, commonly incited local youth groups to organize Rough Music, charivari, shivaree, Katzenmusik, or some similar public ceremony, complete with horn-blowing, pot-thumping, singing or shouting of obscene verses, and display of licentious symbols; until the offenders paid the requested penalty - - which sometimes included leaving the community - the uproar continued. Yet the rough routine twinned with the serenade, a positive shivaree, and often the sequel of a groom's payment to the assembled youths. similar routines helped workers control their local labor markets: riding someone around or out of town on a donkey, a staff, or a rail punished him for violating the rules. (American sailors added the refinement of tar and feathers to their own version of the routine.)

Attacks on profiteers in staple foods, especially grain, took several distinct forms. During the period from 1650 to 1850 , people most often either kept grain from leaving town by seizing 
the shipment or forced local food into the market at a price lower than the owner preferred. The authorities called those actions food riots, but in fact they consisted of ordinary people's doing almost exactly what the authorities themselves commoniy did in time of shortage -- forbid grain from leaving town, commandeer local supplies, regulate the price. Sometimes, in addition to seizing grain or bread, crowds took vengeance on the profiteer occasionally by attacking him personally, but most often by a systematic sacking of his house, shop, or mill.

The routine of sacking usually included the throwing of precious goods into the street for smashing and burning, often featured a raid on the wine cellar, and sometimes ended with the burning or "pulling down" of the structure. Not only bakers and merchants felt its sting. The keeper of a tavern or a brothel who cheated his customers could well see his premises disappear. Now and then, furthermore, a public official who had passed the boundaries of legitimacy lost his house as well; that, Lieutenant Governor Hutchinson of Massachusetts learned in Boston's struggles before the American Revolution.

The era of the American Revolution, indeed, brought a flowering of popular collective action in England and America. John wilkes, the popular leader who came to prominence in the 176øs, rapidly became the symbol of opposition to arbitrary royal 
power; that is why Hogarth portrayed him with a liberty cap on a pike. Wilkes' supporters paraded through the streets demanding illumination in his honor and gathered outside his prison to show their solidarity. Their regalia often included a boot with the figure of a devil in it, a punning symbol for Lord Bute, the king's advisor. Those supporters introduced innovations, such as the expansion of the conventional small petitioning delegation into a march of thousands, that helped create the later means of the demonstration and the social movement.

In wilkes' time, the burning of stamp paper and the christening of a Liberty Tree became standard ways of stating opposition to royal policy on both sides of the Atlantic. The first Liberty Tree stood at the entrance to Boston and held in its branches - : a boot containing the figure of a devil. The keepers of that tree made all passersby act out their alignment with the colonial cause by cursing the boot. When French people made their own revolution after 1789, they made the planting of Liberty Trees one of their standard rituals.

Bostonians and other American colonials, to be sure, took their opposition past symbols and dumb show, not only sacking the houses of royal officials and sympathizers, but also dumping taxed tea in the harbor and braving the king's troops in the streets. They also instituted people's courts, formed militias, staged 
public tributes to wilkes and Liberty, generally renewed the old repertoire by giving it more autonomy and larger references to popular sovereignty.

In England, supporters of the American and French revolutions used similar forms to express their own critique of royal policy. But others used those changing forms as well. Anti-Catholic Lord George Gordon, for example, led his protestant Association in marches through London which ended in the sacking of catholic homes and chapels. And around the elections of the later eighteenth century, despite an electorate restricted to a national elite, supporters and opponents of one faction or another found the way, literally, to show their colors and to fight the hirelings of their enemies.

Revolution and its Repertoire

French people, for their part, began a brief period of innovation with the Revolution of 1789. In burning newly-built tollhouses and breaking into arsenals for weapons to arm their militias, Parisians of July 1789 pushed old-regime routines further than they usually went. In using those militias and weapons to take the Bastille, the very symbol of arbitrary rule, they went to a point that even the greatest previous rebelions had not reached. Yet in killing royal officials who were accused of profiteering in grain, and displaying their heads on pikes, 
they were essentially mimicking the official old-regime ceremonial for the execution of traitors. When, in 1792, people tore down the statue of the king in Paris' Place des victoires, they were duplicating a celebration carried out by citizens of New York in 1770 .

The great days of popular participation in the early Revolution usually involved gathering outside the headquarters of an assembly or an administration, marching on other centers of power, and attacking both. symbols and supporters of the opposition. Revolutionary organizers quickly undertook to capture popular energy. On the one side, revolutionary clubs, committees, and militias proliferated. On the other side, leaders created new secular and republican versions of the old public ceremonies: patriotic holidays, Festivals of the supreme Being, and other occasions on which the old line between participants and spectators dissolved: everyone was supposed to join in. Indeed, at times not to join became rather dangerous. With Napoleon's empire, the regime recaptured control of public ceremonies, reestablished the line between participants and spectators, increasingly substituted the display of military might for that of civic commitment. The Revolution's collective-action innovations did not, for the most part, survive the Thermidorean reaction. With the Restoration of 1815 , the old-regime repertoire again held 
sway.

Nevertheless, in the new revolutionary moments of 1830 and 1848, French people self-consciously revived some of the routines and symbols of the eighteenth-century revolution. The creation of a local military force and the defense of its turf with barricades and street-fighting became more common, occurring not only during the successful revolutions but also in a series of failed insurrections. By the 1830s, the French repertoire was splitting: a set of routines greatly resembling the eighteenth-century forms for most purposes, another set of routines emerging for rare revolutionary action. We can see some pushing and stretching of the old forms, as people gave charivaris and serenades to political leaders and took the occasion of funerals and banquets to broadcast their numbers and determination. Yet on the whole people stuck to the old repertoire.

\section{New Ways in Collective Action}

In England, the new repertoire was clearly emerging. True, in the "Swing" rebellion of 1830, agricultural laborers wrote threatening letters, burned hayricks, smashed threshing machines, and mobbed their employers in good old style. That last laborers' revolt occurred in the company of turnouts, seizures of grain, and other performances familiar to the eighteenth century. Yet for the old forms the last round had come. The retaliatory burning of 
hayricks, and the posting of rewards for the culprits, continued for several decades more. The swing rebellion subsided with the dispatch of royal troops in November 1830. But about the same time a movement for parliamentary reform was taking shape. It bore a number of the stigmata of our own times' social movements: holding public meetings, organizing associations, mounting petition drives, marching through streets, competing for leadership, attempting to manipulate the actions and pronouncements of groups claiming to represent the cause, constant dialogue with powerholders.

Throughout Great Britain, people mobilized for and against different programs of parliamentary reform. They called meetings and marches, claiming victory when many people showed up for them. The same display of numbers and determination occurred in the petitioning of Parliament. Although some of the trappings and rhetoric seem exotic today, the British had created the social movement in something like its present form.

During the next two decades, the old repertoire declined rapidly in importance as the new one consolidated. True, occasions such as Queen Victoria's coronation procession still gave Britons the opportunity to voice approval or disapproval. In France, corporate rituals such as the artisans' cortege, complete with banners and symbolic objects, still served to show a group's 
strength. But the development of a chartist movement in Britain confirmed the role of mass meetings, associations, and demonstrations in national politics, as in France the growth of organized republican and royalist movements laid the ground for a similar transformation.

With the French revolution of 1848 came another cornucopia of clubs, mutual-aid societies, citizen militias, assemblies, demonstrations, and battles in the streets. By 1850, Louis Napoleon's increasingly repressive regime had succeeded in subduing most working-class and republican collective action of any sort. The major insurrection inspired by Louis Napoleon's 1851 coup d'etat failed to stop the swing toward authoritarian rule, and a last round of food riots in 1853-54 recalled the old regime. By the end of the $1850 \mathrm{~s}$, nevertheless, the demise of the old repertoire and the vigor of the new were quite visible.

\section{Surveys and strikes}

During the same general period, the idea and practice of surveying individuals, households, and firms to determine the state of the country came into their own. Now and then before 1800 amateur demographers, assiduous tax collectors, and curious royal officials had occasionally mounted something like a survey to assess the state of their world, but little came of those intermittent efforts. Mid-century censuses, the rising popularity 
of the sort of publication called almanac, statistique, or directory, and the emergence of the scientific social reformer a Ia Mayhew or Parent-Duchatelet heralded a new day of populist inquiry, neatly paraliel to the development of social movements demanding places for the dispossessed in the national structure of power, and nicely tuned to the concern of the wealthy and powerful to know the nature of the beast that now roared below.

Thus authorities shaped a regular apparatus for collecting information from and about individuals, even individuals at the margins of urban life like London's vagrants. Thus social surveyors standardized their devices for collecting and presenting information: interview schedules, statistical tables, maps of social problems.

Among those collections of data, the first compilations of regular strike statistics began to appear, roughly in cadence with the legalization of strikes and trade unions, during the later nineteenth century. In London, match girls, dockers, and many others organized. Over a wide range of industries, the firm-by-firm strike became a showpiece of the workers' repertoire. Government officials acquired a heightened interest not only in tallying strikes, but also in policing them.

By the end of the nineteenth century, in most western countries May Day had become a moment for the display of workers' 
numbers and determination. Many strikes -- for example, the Parisian omnibus strike of 1891 - brought violent encounters between workers and police, strikebreakers, or agents of employers. A minority of strikes, in fact, went on with a display of revolutionary symbols, language, and action: red flags, anarcho-syndicalist watchwords, barricades in the streets.

Strikes coupled loosely with demonstrations, with the strike itself aiming especially at the boss, while the demonstration carried a message to authorities and the general public. Since tolerance from authorities and credit from shopkeepers often contributed mightily to a strike's success, the outside show of strength was no mere flourish.

Although manufacturing workers figured prominently in strikes and demonstrations, non-manufacturing workers such as dockers and miners sometimes had even greater records of militancy. Agricultural workers, on the whole, rarely mounted large-scale coordinated actions. But when they did, the actions could be formidable. A case in point is the French winegrowers' movement of 1907, which produced demonstrations and meetings involving tens of thousands, and put strong pressure on the government to guarantee prices and markets.

\section{Our Twentieth Century}

During the early twentieth century, it became standard 
demonstrators' practice to carry signs and banners with texts summarizing their identities and grievances. That was a shift from an earlier use of flags and symbols. Battles with the police - rarely won by demonstrators -- remained a standard feature of workers' public appearances, since police who did not attack first typically marked boundaries the workers should not cross, and workers typically showed their determination by taunting the police and challenging the boundaries.

As under the old repertoire, the range of gatherings in a given form ran from quite official to very oppositional. At both ends of the range, the rationale of a demonstration, parade, or open-air meeting was to bring many people into a public place for a show of commitment to a common cause. Leon Blum's address to his followers during the Popular Front of 1936 and the Liberation cortege that passed through the place de la concorde in 1944 had at least that much in common.

The great moments of May and June 1968 produced a fascinating combination of standard repertoire items with creative invention. Extraordinary graffiti and posters accompanied occupations of schools, factories, and public streets, but occurred in the company of more or less conventional demonstrations and strikes.

Paris, especially, blossomed with slogans, posters, handbills, and wall paintings, as student rebels claimed the 
streets and built barricades with paving stones. While students railed against regimentation, corruption, and the vietnam war, various groups of workers demanded more control over their workplaces, better return for their labor, different government policies, or all three. In Nantes, Breton farmers deployed a kind of demonstration they had been using for a decade or so: the slow, or stopped, cortege of tractors in mid-city, coupled with the ostentatious distribution and destruction of produce for which the price was too low.

Paris and France were the fountainhead of the 1968 movements. Yet the movements extended onto the campuses of North American universities. Never before or since have we seen such a sustained employment of that special twentieth-century collective-action feature, the occupation and control of a contested space. claiming and reclaiming space included the creation of sanctuaries, homes, recreation areas and - emphatically -- parks in vacant buildings and on abandoned land. As in People's Park, Berkeley, that attempt frequently thrust the occupiers into direct confrontation with the owners, managers, and regulators of both private and public property.

Struggles over the right to occupy spaces did not entirely disappear with the passing of 1968. In Boston and Cambridge, for example, tenants' rights groups staged demonstrations, met on the 
state capitol steps, and dared the Redevelopment Authority to eject them from condemned housing. In the Boston area, organizers of the tenants' movement dramatized their message by erecting conspicuous "tent cities" for the ill-housed, organized rent strikes, and linked the cause to resistance against destruction of dwellings for major highways. Yet by and large they adopted the century-old established means: meetings, demonstrations, petitions and the other standard paraphernalia of social movements.

In London and paris as well, when people wanted to manifest their numbers and determination on behalf of a demand, complaint, or program, they continued to demonstrate in ways greatly resembling those of London's workers in 1848. In 1982, when the French communist party and its labor-union affiliates staged a large March for Peace on a pleasant Sunday in June, it took shape as a police-protected parade, banners rippling and chants sounding, from the Gare Montparnasse to the Place de la Bastille.

In 1983, 1ikewise, Paris' May Day parade-demonstration had quite a traditional air: Despite the presence of sound trucks, helium balloons, a Women's National Union, a gay delegation chanting heteros, hOMOS, ALL TOGETHER: SAME BOSSES, SAME STRUGGLE, opposition groups from Poland, Iran, Palestine, Lebanon, and Turkey, a jazz band or two, and vendors of sausage sandwiches, the march ended at the site of the long-gone Bastille, with speeches 
congratulating workers and the Left on their display of numbers, strength, and solidarity, then exhorting them to build more of each. The nineteenth-century demonstration was alive and well.

\section{Conclusion}

Now, I realize that my capsule history has the air of a comic strip: quick sketches, brief captions, garish colors. I have kept entirely silent about the technical problems of collecting and analyzing the available evidence concerning popular collective action, which is my daily preoccupation and probably the closest point of approach between your research and mine. I have brushed aside crucial details, such as the persistence of British struggles over food prices, in the form of physical attacks on the shops of profiteers, into the $1870 \mathrm{~s}--$ well after seizures of grain had disappeared. I have almost entirely neglected the causes of change in collective-action repertoires, which depend in the large on the development of industrial capitalism and the growth of centralized national states, and in the small on the strategic interactions of particular pairs of antagonists.

My sins do not end there. I have also sidestepped the crucial problem of discrepancies between people's interests, grievances or aspirations and their ability to act on them. I have foreshortened the differences among France, Britain, and the United States, which result largely from the different paths and 
paces of state-making and capitalism in the three countries. I have made it seem as though there were only two alternative repertoires, when the division between "old" and "new" averages over a great many subtle distinctions and transformations. To get the changes right, we would have to plunge far deeper into the stream of collective action than our brief moment together allows. Yet I hope my cartoons convey four messages clearly. First, in our own world most people pursue collective action, when they do, by means of a limited number of alternative forms whose essential features have been in place for over a century. Second, our current collective-action repertoire displaced a very different but quite viable set of forms that prevailed for two hundred years or so before the early nineteenth century. Third, the older repertoire gave ordinary people extensive means of speaking their minds in the absence of elections, surveys, and social movements. Fourth, actions in the older and newer repertoires have left behind traces that, with proper attention, yield rich information about the interests, grievances, and aspirations of our predecessors in this world. Even today we can reasonably look to the language of popular collective action as a complement to the knowledge offered us by elections and surveys. 


\section{REFERENCES}

NOTE: This bibliography illustrates the sort of material that is available concerning the changing forms of collective action in Europe and America, without making any pretense of covering the literature. It concentrates on books, and favors sources containing maps and visual images of popular collective action.

Yves-Marie Berce

1976 Fete et revolte. Des mentalites populaires du XVIe au XVIIIe siecle. Paris: Hachette.

John Bohstedt

1983 Riots and Community Politics in England and Wales, 179ø-1810. Cambridge: Harvard University Press.

John Brewer and John Styles

1980 eds., An Ungovernable People. Law in the Seventeenth and Eighteenth Centuries. London: Hutchinson.

Brian Brown

1981 "Industrial Capitalism, Conflict, and Working-class Contention in Lancashire 1842," in Louise A. Tilly and Charles Tilly, eds., class Conflict and collective Action. Beverly Hills: Sage.

Richard Maxwell Brown

1975 Strain of Violence. Historical studies of American Violence and Vigilantism. New York: Oxford University Press.

Manuel Castells et al.

1974 Sociologie des mouvements sociaux urbains. Enquete sur la Region Parisienne. Paris: Ecole des Hautes Etudes en Sciences Sociales. 2 vols.

Andrew Charlesworth

1983 ed., An Atlas of Rural Protest in Britain, 1548-19ø0. London: Croom Helm.

Alfred Cobban

1969 ed., The Eighteenth Century. Europe in the Age of Enlightenment. New York: McGraw-Hill. 
Edward Countryman

1976 "'Out of the Bounds of the Law': Northern Land Rioters in the Eighteenth Century," in Alfred F. Young, ed., The American Revolution. DeKalb: Northern Illinois University Press.

James E. Cronin and Jonathan Schneer

1982 eds., Social Conflict and the political order in Modern Britain. London: Croom Helm.

Natalie Zemon Davis

1975 Society and Culture in Early Modern France. Berkeley: University of California Press.

Alain Delale and Gilles Ragache

1978 La France de 68. Paris: Seuil.

William J. Fishman

1979 The Streets of East London. London: Duckworth.

William A. Gamson

1975 The Strategy of Social Protest. Homewood, Illinois: Dorsey.

M.D. George

1925 London Life in the XVIIIth Century. London: Kegan Paul, Trench, Trubner.

John R. Gillis

1974 Youth and History. Tradition and Change in European Age Relations, 1770-Present. New York: Academic Press.

D.V. Glass

1973 Numbering the People. Farnborough, Hants.: Saxon House.

Robert Goodman

1971 After the Planners. New York: Simon and Schuster.

Hugh Davis Graham and Ted Robert Gurr

1979 Violence in America. Historical and Comparative Perspectives. Beverly Hills: Sage. Revised edition.

Michael P. Hanagan 
$198 \emptyset$ The Logic of Solidarity. Artisans and Industrial Workers in Three French Towns, 1871-1914. Urbana: University of Illinois Press.

Douglas Hay and others

1975 Albion's Fatal Tree. Crime and Society in Eighteenth-Century England. New York: Pantheon.

Michael S. Hindus

1971 "A City of Mobocrats and Tyrants: Mob Violence in Boston, 1741-1863," Issues in Criminology 6: 55-83.

E.J. Hobsbawm and George Rude

1969 Captain Swing. London: Lawrence \& Wishart.

Dirk Hoerder

1977 Crowd Action in a Revolutionary society: Massachusetts, 1765-178ø.

David Jones

1982 Crime, protest, Commmunity, and Police in Nineteenth-Century Britain. London: Routledge \& Kegan Paul.

Paul F. Lazarsfeld

1982 (Patricia L. Kendall, ed.) The Varied Sociology of Paul F. Lazarsfeld. New York: Columbia University Press.

Jacques Le Goff and Jean-Claude Schmitt

1981 eds., Le Charivari. Paris: Ecole des Hautes Etudes en Sciences Sociales.

Jesse Lemisch and John K. Alexander

1972 "The White Oaks, Jack Tar, and the Concept of the 'Inarticulate'" William and Mary Quarterly 29: $109-142$.

Pauline R. Maier

1972 From Resistance to Revolution. Colonial Radicals and the Development of American Opposition to Britain, 1765-1776. New York: Random House.

Henry Mayhew

1967 London Labour and the London Poor: A cyclopaedia of the conditions and earnings of those that will work, 
those that cannot work, and those that will not work. London: Cass. 4 vols. First published as articles in 1849-50 and in book form in 1861-62.

Doug McAdam

1982 Political process and the Development of Black Insurgency, 1930-1970. Chicago: University of Chicago Press,

John M. Merriman

1975 ed., 1830 in France. New York: New Viewpoints.

Wolfgang J. Mommsen and Gerhard Hirschfeld

1982 eds., Social protest, Violence, and Terror in Nineteenth- and Twentieth-Century Europe. New York: St. Martin's.

Musée de l'Affiche et de la Publicité

1982 Images de la Révolte, 1965-1975. Paris: Henri Veyrier.

Alexandre Parent-Duchatelet

1981 La Prostitution à Paris au XIXe siècle. Paris: Seuil. First published in 1836 .

Rémy Pech

1975 Entreprise viticole et capitalisme en LanguedocRoussilion du Phylloxera au crises, de mévente. Toulouse: Publications de l'Universite de Toulouse Le Mirail.

Michelle Perrot

1974 Les ouvriers en grève. France, 1871-1890. Paris: Mouton. 2 vols.

Leon Radzinowicz

1968 A History of English Criminal Law and its Administration from 1750. IV: Grappling for Control. London: Stevens.

Marcel Reinhard

1971 Nouveḷle Histoire de Paris. La Révolution, 1789-1799. Paris: Diffusion Hachette.

Howard C. Rice, Jr.

1976 Thomas Jefferson's Paris. Princeton: Princeton 
University Press.

George Rudé

1964

The Crowd in History. New York: Wiley.

Walter J. Shelton

1973 English Hunger and Industrial Disorders: A Study of Social Conflict During the First Decade of George III's Reign. London: Macmillan.

John Stevenson

1979 Popular Disturbances in England, 17øø-187ø. London: Longmans.

E.P. Thompson

1975 Whigs and Hunters. The origin of the Black Act. New York: Pantheon.

Eileen Yeo and Stephen Yeo

1981 eds., Popular Culture and class Conflict, 159ø-1914. Explorations in the History of Labour and Leisure. Brighton: Harvester. 